\title{
PReS-FINAL-2140: Neutropenia with Tocilizumab (TCZ) treatment is not associated with increased infection risk in patients with systemic juvenile idiopathic arthritis (SJIA)
}

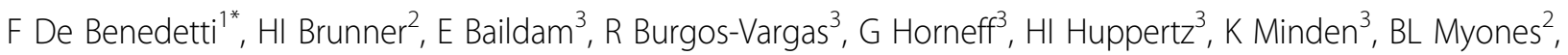

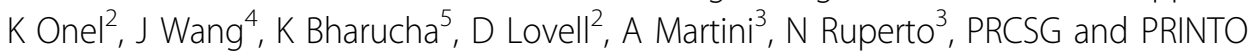

From 20th Pediatric Rheumatology European Society (PReS) Congress

Ljubljana, Slovenia. 25-29 September 2013

\section{Introduction}

In the phase 3 TENDER trial of TCZ in patients with sJIA, decreases in neutrophil count were commonly observed.

\section{Objectives}

To determine if neutropenia was associated with increased risk of infection and to investigate variables associated with development of neutropenia in patients treated with TCZ for up to 2 years in TENDER.

\section{Methods}

112 children with active, persistent sJIA were randomised $2: 1$ to receive TCZ by body weight $(12 \mathrm{mg} / \mathrm{kg}<30 \mathrm{~kg}$ or $8 \mathrm{mg} / \mathrm{kg} \geq 30 \mathrm{~kg}$ ) or placebo IV every 2 weeks for 12 weeks and continued in an ongoing, TCZ open-label extension. [1]. Worst common toxicity criteria (CTC) neutropenia grade (grade $1, \geq 1.5$ and $<2.0 \times 10^{9} / \mathrm{L}$; grade $2, \geq 1.0$ and $<1.5 \times 10^{9} / \mathrm{L}$; grade $3, \geq 0.5$ and $<1.0 \times 10^{9} / \mathrm{L}$; grade $4,<0.5$ $\left.\times 10^{9} / \mathrm{L}\right)$ and lowest observed neutrophil count $\left(10^{9} / \mathrm{L}\right)$ were identified for each patient. Univariate linear regression analysis was performed to investigate association of patient characteristics with lowest observed neutrophil count. Rates of infections and serious infections (per 100 patient years [PY]) in periods \pm 15 days around grade1-2 neutropenia (22.9 PY) and around grade 3-4 neutropenia (5.5 PY) were compared to corresponding rates in periods with normal neutrophil count (173.6 PY).

\section{Results}

Up to week 104, 64/112 patients (57.1\%) had at least 1 episode of grade 1-4 neutropenia; worst grade: $1(\mathrm{n}=2)$, $2(\mathrm{n}=34), 3(\mathrm{n}=26)$ and $4(\mathrm{n}=2)$. Rates of infections and serious infections during period of normal neutrophil counts $(276.5 / 100 \mathrm{PY}$ [95\% CI 252.3, 302.3] and 11.5/ 100PY [95\% CI 7.0, 17.8], respectively) were comparable to those observed \pm 15 days around grade 1-2 neutropenia (226.7/100PY [95\% CI 169.3, 297.3]; 8.7/100PY [95\% CI $1.1,31.5])$ and grade $3-4$ neutropenia $(292.5 / 100 \mathrm{PY}$ [95\% CI 167.2, 475.0]; 0/100PY), with no trend towards increased risk with higher grade neutropenia. Methotrexate (MTX) use (Yes/No) was significantly associated with lowest observed neutrophil count (difference: - 0.575 [95\% CI: $-1.02,-0.13$ ],$p=0.012$ ), with $62 \%$ of 77 patients receiving MTX vs $46 \%$ of 35 patients not receiving MTX having grade 1-4 neutropenia. Younger age was borderline associated with lowest observed neutrophil count $(\beta=0.04661$, $p=0.047)$. Concurrent use of glucocorticoids (GC) and TCZ exposure were not associated with lowest observed neutrophil count $(p>0.3)$.

\section{Conclusion}

No trend for association between neutropenia and increased risk of infections was observed in the TENDER trial. Background MTX, and somewhat younger age, was associated with increased risk for neutropenia, while TCZ exposure and concurrent GC use were not.

\section{Disclosure of interest}

F. De Benedetti Grant/Research Support from: Abbott, Pfizer, BMS, Roche, Novimmune, Novartis, SOBI, H. I. 
Brunner Consultant for: Novartis, Genentech, MedImmune, EMD Serono, AMS, Pfizer, UCB, Janssen, Speakers Bureau: Genentech, E. Baildam: None Declared, R. BurgosVargas Grant / Research Support from: Abbott, Consultant for: Abbott, BMS, Janssen, Pfizer, Roche, Speakers Bureau: Abbott, BMS, Janssen, Pfizer, Roche, G. Horneff Grant/ Research Support from: Abbott, Pfizer, H. I. Huppertz Consultant for: Abbott, Chugai, Pfizer, Roche, Swedish Orphan, K. Minden Grant / Research Support from: Pfizer, Abbvie, Consultant for: Pfizer, Abbvie, Roche, Chugai, Medac, B. L. Myones: None Declared, K. Onel: None Declared, J. Wang Employee of: Roche, K. Bharucha Employee of: Genentech, D. Lovell Grant / Research Support from: NIH, Consultant for: AstraZeneca, Centocor, Janssen, Wyeth, Amgen, Bristol-Meyers Squibb, Abbott, Pfizer, Regeneron, Hoffmann-La Roche, Novartis, Genentech, Speakers Bureau: Roche, Genentech, A. Martini Grant / Research Support from: Abbott, AstraZeneca, BMS, Centocor, Lilly, Francesco Angelini, GSK, Italfarmaco, MerckSerono, Novartis, Pfizer, Regeneron, Roche, Sanofi Aventis, Schwarz Biosciences, Xoma, Wyeth, Consultant for: Abbott, AstraZeneca, BMS, Centocor, Lilly, Francesco Angelini, GSK, Italfarmaco, MerckSerono, Novartis, Pfizer, Regeneron, Roche, Sanofi Aventis, Schwarz Biosciences, Xoma, Wyeth, Speakers Bureau: Abbott, Boehringer, BMS, Novartis, Astellas, Italfarmaco, MedImmune, Pfizer, Roche, N. Ruperto Grant / Research Support from: Abbott, AstraZeneca, BMS, Centocor, Lilly, Francesco Angelini, GSK, Italfarmaco, MerckSerono, Novartis, Pfizer, Regeneron, Roche, Sanofi Aventis, Schwarz Biosciences, Xoma, Wyeth, Consultant for: Abbott, AstraZeneca, BMS, Centocor, Lilly, Francesco Angelini, GSK, Italfarmaco, MerckSerono, Novartis, Pfizer, Regeneron, Roche, Sanofi Aventis, Schwarz Biosciences, Xoma, Wyeth, Speakers Bureau: Abbott, Boehringer, BMS, Novartis, Astellas, Italfarmaco, MedImmune, Pfizer, Roche.

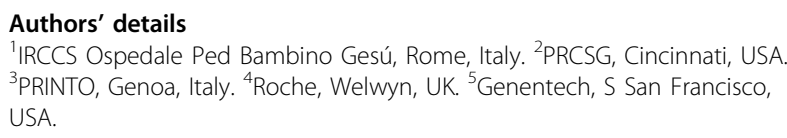

Published: 5 December 2013

\section{Reference}

1. De Benedetti F, et al: N Engl J Med 2012, 367:2385.

doi:10.1186/1546-0096-11-S2-P152

Cite this article as: De Benedetti et al:: PReS-FINAL-2140: Neutropenia

with Tocilizumab (TCZ) treatment is not associated with increased

infection risk in patients with systemic juvenile idiopathic arthritis

(SJIA). Pediatric Rheumatology 2013 11(Suppl 2):P152.

\section{Submit your next manuscript to BioMed Central} and take full advantage of:

- Convenient online submission

- Thorough peer review

- No space constraints or color figure charges

- Immediate publication on acceptance

- Inclusion in PubMed, CAS, Scopus and Google Scholar

- Research which is freely available for redistribution

Submit your manuscript at www.biomedcentral.com/submit 